\title{
Correction to: Determination of phthalates in particulate matter and gaseous phase emitted in indoor air of offices
}

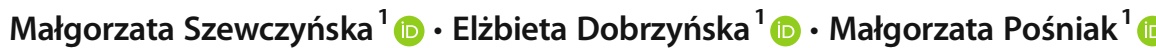

Published online: 4 December 2020

(C) The Author(s)

\section{Correction to: Environmental Science and Pollution Research https://doi.org/10.1007/s11356-020-10195-3}

The article Determination of phthalates in particulate matter and gaseous phase emitted in indoor air of offices, written by Małgorzata Szewczyńska, Elżbieta Dobrzyńska and Małgorzata Pośniak, was originally published electronically on the publisher's internet portal on 22 September 2020 without open access. With the author(s)' decision to opt for Open Choice the copyright of the article changed on 22 July 2020 to (C) The Author(s) 2020 and the article is forthwith distributed under a Creative Commons Attribution 4.0 International License, which permits use, sharing, adaptation, distribution and reproduction in any medium or format, as long as you give appropriate credit to the original author(s) and the source, provide a link to the Creative Commons license, and indicate if changes were made. The images or other third party material in this article are included in the article's Creative Commons license, unless indicated otherwise in a credit line to the material. If material is not included in the article's Creative Commons license and your intended use is not permitted by statutory regulation or exceeds the permitted use, you will need to obtain permission directly from the copyright holder. To view a copy of this license, visit http://creativecommons. org/licenses/by/4.0.

The Original article has been corrected.

Open Access This article is licensed under a Creative Commons Attribution 4.0 International License, which permits use, sharing, adaptation, distribution and reproduction in any medium or format, as long as you give appropriate credit to the original author(s) and the source, provide a link to the Creative Commons licence, and indicate if changes were made. The images or other third party material in this article are included in the article's Creative Commons licence, unless indicated otherwise in a credit line to the material. If material is not included in the article's Creative Commons licence and your intended use is not permitted by statutory regulation or exceeds the permitted use, you will need to obtain permission directly from the copyright holder. To view a copy of this licence, visit http://creativecommons.org/licenses/by/4.0/.

Publisher's note Springer Nature remains neutral with regard to jurisdictional claims in published maps and institutional affiliations.

The online version of the original article can be found at https://doi.org/ $10.1007 / \mathrm{s} 11356-020-10195-3$

Małgorzata Szewczyńska

mapol@ciop.pl

1 Department of Chemical Aerosol and Biological Hazards, Central Institute for Labour Protection - National Research Institute, Czerniakowska 16, 00-701 Warsaw, Poland 